\title{
THE GOPHER-CROW FIGHT
}

KEITH BARR, 40 Richardson Crescent, Regina, Saskatchewan. S4S 4J3

One summer while in the industrial part of the city I notice a crow standing on the ground. There are also several gophers (ground squirrels) of different sizes gathered around the crow. The gophers seem rather annoyed with the crow.

I notice that there seems to be a confrontation between the crow and a certain half-grown gopher. They are facing each other, about a foot apart. The young gopher would lunge at the crow who would jump back. The crow would advance on the gopher but it would hold its ground and scream insults at the crow. The other gophers would move toward the crow one at a time, but if the crow moved they would scamper back to their holes. Even a large go- pher, which I take to be the young gopher's mother, retreats. The standoff between the crow and the young gopher lasts three or four minutes. The crow attacks the gopher several times by pecking the gopher on the head and jumping back. The young gopher is still as defiant as ever and gives no ground. After one attack, I see that the gopher is hurt. The crow attacks again. The fight is over. The crow is the victor.

I have seen crows eat mice by swallowing them whole but did not know that they could kill a half-grown gopher.

- Keith Barr, 40 Richardson Crescent, Regina, Saskatchewan. S4S $4 \mathrm{~J} 3$

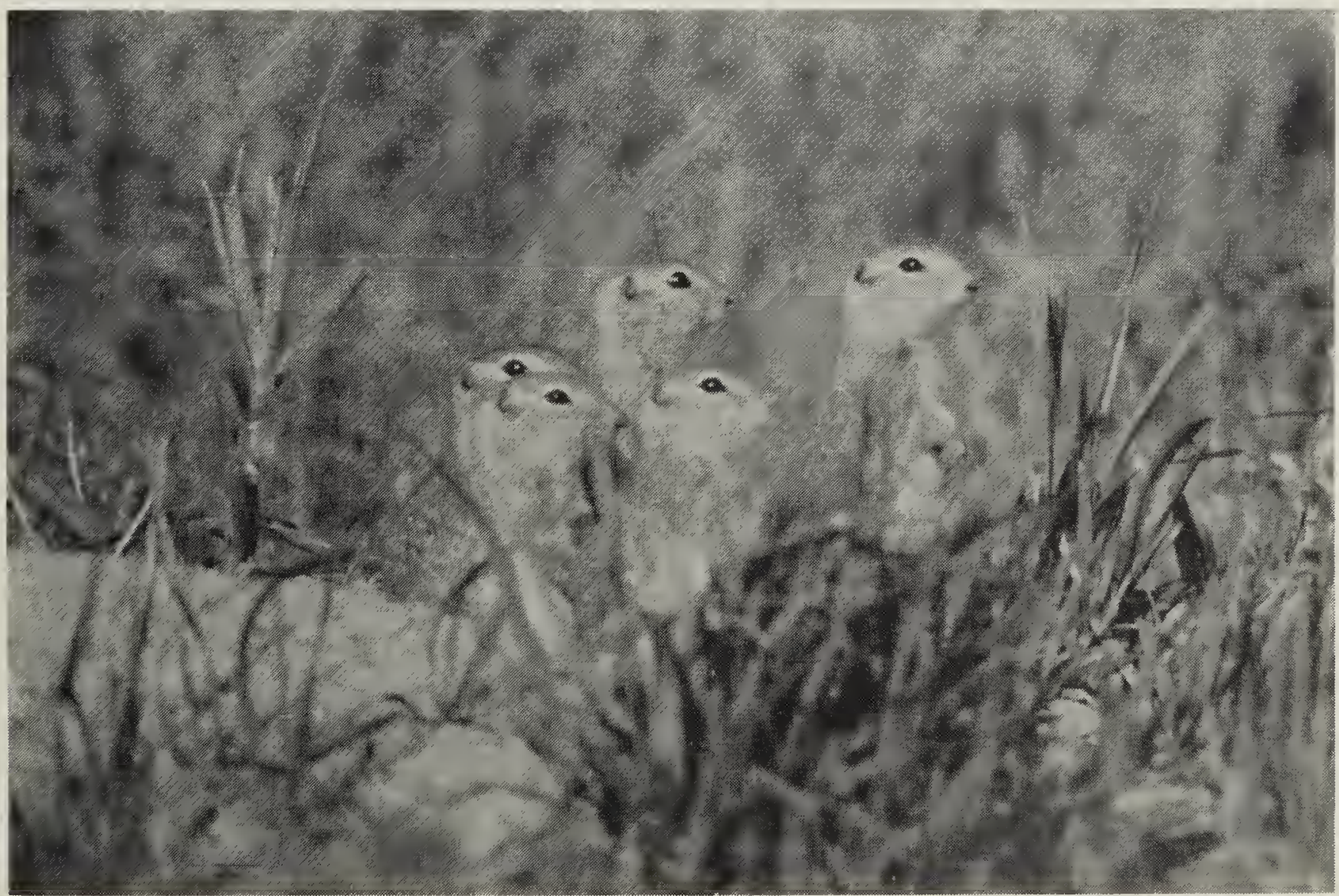

